\title{
REVISTAMARACANAN
}

Artigo

\section{Jurisdição e subordinação: tentativas de provincialização da Igreja no Piauí (1822-1830)}

\author{
Jurisdiction and subordination: attempts to provincialize the Church in \\ Piauí (1822-1830)
}

\author{
João Vitor Araújo Sales* \\ Universidade Federal do Piauí \\ Teresina, Piauí, Brasil \\ Marcelo de Sousa Neto** \\ Universidade Estadual do Piauí \\ Teresina, Piauí, Brasil
}

Recebido em: 16 fev. 2019.

Aprovado em: 08 jul. 2019.

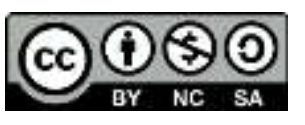

\footnotetext{
* Mestre em História do Brasil e Bacharel em História pela Universidade Federal do Piauí. (vitorjhon7@gmail.com)

ORCID iD: https://orcid.org/0000-0002-7808-9362

CV Lattes: http://lattes.cnpq.br/0149013316340058
}

\footnotetext{
** Professor Associado da Universidade Estadual do Piauí - UESPI, Campus Clóvis Moura. Professor da Pós-graduação em História do Brasil da Universidade Federal do Piauí - UFPI. Doutor em História pela Universidade Federal de Pernambuco; Mestre em Educação pela UFPI; Especialista em História Política Contemporânea pela UESPI e em História Sociocultural pela UFPI; Licenciado em História e Bacharel em Direito pela UESPI.

ORCID iD: https://orcid.org/0000-0002-2748-2316

CV Lattes: http://lattes.cnpq.br/2608763010341838
} 


\title{
Resumo
}

O presente artigo analisa as primeiras tentativas de provincialização, apropriação política, da Igreja Católica no Piauí. Considerando que o Piauí esteve sob o controle político-administrativo do Maranhão até 1811, entende-se que as famílias pertencentes à elite econômica local atuaram de forma articulada no intuito de trazer para a província o controle sobre a Igreja, a partir da concepção desta enquanto estrutura de poder legítima, de modo a exercer jurisdição própria sobre o governo espiritual na forma de uma diocese ou organismo semelhante que atendessem seus interesses locais. Para análise, investigou-se a atuação dos deputados piauienses nas Cortes de Lisboa (1822), bem como, da elite local nos primeiros órgãos de governo provincial: o Conselho de Presidência e o Conselho Geral. Percebeu-se, a partir das atas, discussões e resoluções dos representantes nos Conselhos, e a defrontação destas com a bibliografia concernente, que uma elite local coesa tentou reiteradamente territorializar a Igreja no âmbito da província do Piauí, de modo a exercer poder diretamente sobre ela, todavia, obstruído pela influência do prelado maranhense e a indiferença do Governo Central à causa do Piauí.

Palavras-chave: Igreja Católica. Provincialização. Piauí. Maranhão.

\begin{abstract}
This article analyzes the first attempts at provincialization and political appropriation of the Catholic Church in Piauí. Considering that Piauí was under the political-administrative control of Maranhão until 1811, it is understood that the families belonging to the local economic elite acted in an articulated way in order to bring to the province the control over the Church, from the conception of this one while structure of legitimate power in order to exercise proper jurisdiction over spiritual government in the form of a diocese or similar organization that would serve their local interests. For analysis, the deputies in Piauí were investigated at Lisbon Courts (1822), as well as the local elite in the first provincial government organizations: the Presidency Council and the General Council. It became clear from the minutes, discussions and resolutions of the representatives in the Councils, and the confrontation of these with the relevant bibliography, that a cohesive local elite tried repeatedly to territorialize the Church within the province of Piauí, in order to exercise power directly over it, however, obstructed by the influence of the prelate of Maranhão and the indifference of the Central Government to the cause of Piauí.
\end{abstract}

Keywords: Catholic Church. Provincialization. Piauí. Maranhão. 


\section{Introdução}

A forte atuação da Igreja Católica fez-se sentir em todo percurso de ocupação do Brasil pelo Estado português, adequando-se às diversas necessidades que emergiam daquela paulatina e complexa colonização, como observado por Laura de Melo e Souza, destacando ainda que "a fé não se apresentava isolada da empresa ultramarina: propagavase a fé, mas colonizava-se também. As caravelas portuguesas eram de Deus, nelas navegavam juntos missionários e soldados". ${ }^{1}$ Dessa forma, a propagação da fé, materializada àquele instante pelos padres, ritos e dogmas católicos, trouxe para Colônia uma Igreja. Esta aliança estabelecida entre Igreja e Estado deu-se pelo regime do padroado régio, que se operava por uma simbiose mutualística, isto é, o trono sustentava o altar, e, reciprocamente, o altar amparava o trono. ${ }^{2}$ Desta relação decorreram os conflitos de interesses nos primórdios euro-civilizatórios, em diferentes níveis, continuados enquanto esta política sacro-estatizante vigorava. Os territórios de poder nato da Igreja, isto é, os bispados e dioceses, onde se deveria sentir toda pujança dos representantes eclesiais, tinham papel fundamental naquela ordem estabelecida. Destas zonas próprias de poder, atuavam os bispos não apenas na dimensão religiosa, que por si só já influenciava as relações sociais mais diversas, o que passava pela tentativa de controle das consciências de homens e mulheres. ${ }^{3}$

A atuação eclesial sobre as unidades básicas da tessitura social, isto é, a família, como também nas instâncias administrativas do Estado, figurava como local de poder estratégico na estrutura governativa, espaços que, no caso do Piauí, foram assumidos pelas famílias da elite política local. ${ }^{4}$ As ações na busca de uma maior autonomia religiosa para o Piauí resultaram do entendimento que o exercício do poder na Província não se efetivava apenas por meio das instâncias civis. De fato, o governo espiritual tinha sua importância na distribuição de poder, disputado à base de posse, prestígio e formação para ocupação de espaços na ordem construída ou a se constituir. ${ }^{5}$

O Piauí, não estava desconexo desta realidade. É o que se permite afirmar ao analisar com rigor as atas do Conselho de Presidência da Província e as discussões e resoluções do

\footnotetext{
${ }^{1}$ SOUZA, Laura de Melo e. O diabo e a Terra de Santa Cruz: feitiçaria e religiosidade popular no Brasil colonial. São Paulo: Companhia das Letras, 1986, p. 33.

2 HORNAERT, Eduardo; et al. História da Igreja no Brasil: ensaio de interpretação a partir do povo: primeira época - período colonial. 5a ed. Petrópolis, RJ: Vozes, 2008, p. 156.

3 SANTIROCCHI, Ítalo Domingos. Questão de Consciência: os ultramontanos no Brasil e o regalismo do Segundo Reinado (1840-1889). Belo Horizonte: Fino Traço, 2015, p. 116.

${ }^{4}$ SANTIROCCHI. Ítalo Domingos. O Matrimônio no Império do Brasil: Uma questão de Estado. Revista Brasileira de História das Religiões, Maringá (SP), Anpuh, ano IV, n. 12, jan. 2011, p. 82-83. Disponível em: http://dhi.uem.br/gtreligiao/index.html. Acesso em: 12 ago. 2014.

${ }^{5}$ Cf.: CARVALHO, José Murilo de. A construção da ordem: a elite política imperial. Teatro de sombras: a política imperial. $4^{a}$ ed. Rio de Janeiro: Civilização Brasileira, 2008.
} 
Conselho Geral de Província, onde se verifica um ranço dos piauienses em relação ao Maranhão, o que pode ser entendido a partir da separação recente do governo temporal entre as duas regiões. Desta forma, apesar da separação do governo temporal, que passou a ser controlado pelas elites piauienses a partir de 1811, persistia a dependência eclesiástica do Piauí em relação ao Maranhão.

Não era, pois, de se estranhar que, tão logo tenha o Piauí conquistado sua autonomia política do Maranhão, quisesse, pelas suas elites, conquistar o governo pleno por meio da criação de uma diocese separada, independente. A manifestação deste sentimento começou num dos eventos de maior impacto para a transição da Colônia para o Império, as Cortes Extraordinárias da Nação Portuguesa ou, simplesmente, as Cortes de Lisboa. ${ }^{6}$

\section{As Cortes de Lisboa e a "Diocese" do Piauí}

Foi em 1822, quando a estrutura político-administrativa do Piauí estava relativamente formada nos moldes do domínio lusitano, que emergiu a primeira tentativa de provincialização da Igreja no Piauí, isto é, a criação de uma diocese ou estrutura semelhante, independente do bispado do Maranhão.

Devido ao padroado colonial em vigor, era pela política que se poderiam operar mudanças na estrutura eclesiástica das capitanias. ${ }^{7}$ Desta feita, a elite política, que no Piauí

\footnotetext{
${ }^{6}$ O bloqueio continental (1806), imposto a Portugal e aos parceiros comerciais da Inglaterra reordenou o cenário europeu a partir das tensões imperialistas bonapartistas, refletindo na América Portuguesa. $O$ regente do reino português, D. João, preferiu a aliança com os ingleses, propiciando a interiorização da metrópole para a colônia no Brasil, o que exigiu melhorias para continuidade e desenvolvimento do reino nos trópicos. Quando, em junho de 1815, Napoleão foi derrotado, o retorno a Portugal era possível, todavia, a escolha de D. João foi de permanecer no Brasil, e elevá-lo à condição de Reino Unido a Portugal e Algarves, em dezembro do mesmo ano da queda de Napoleão. O descontentamento dos portugueses residentes em Portugal crescia à medida que perdiam a hegemonia política e o controle econômico. Neste contexto, o viés liberal que avançava sobre os regimes absolutistas frutificou, e a exemplo da Espanha, que em março de 1820 fez seu rei jurar uma Constituição, os liberais do Porto se insurgiram, defendendo "a participação do povo nos negócios públicos [...] com as modificações adequadas às ideias do tempo e com as garantias necessárias [...] que, em última análise, se traduziria a constituição que os procuradores da nação, convocados pelos revolucionários, pretendiam então fazer". CARVALHO, Manuel Emílio Gomes de. Os deputados brasileiros nas Cortes Gerais de 1821. Brasília: Senado Federal, 2003, p. 22. Logo, em agosto de 1820, constituíram-se as Cortes, onde se exigia uma Constituição promulgada, nos moldes da espanhola, e reclamava-se a volta do rei para Portugal, na chamada "revolução constitucionalista do Porto". Pressionado a submeter-se à futura Constituição, D. João estabeleceu instruções para eleição dos representantes brasileiros nas Cortes, retornando, posteriormente, a Portugal. Quando as decisões das Cortes evidenciaram seu propósito recolonizador, impossibilitando, mesmo, uma monarquia dual, as ideias em prol da Independência se fortaleceram, de modo que, em reação às ofensivas luso-europeias de agosto de 1822, foi proclamada a Independência do Brasil, concomitantemente à realização das Cortes. Cf.: CARVALHO, Manuel Emílio Gomes de. Os deputados brasileiros nas... Op. cit.; GARCIA, Javier J. Bravo (coord.). História do Brasil Nação: 1808-2010. Vol. 1: Crise colonial e independência, 1808-1830. Madrid; Rio de Janeiro: Fundación Mapfre; Objetiva, 2011; COSTA, Emília Viotti da. Introdução ao estudo da emancipação política do Brasil. In: Da Monarquia à República: momentos decisivos. 9a ed. São Paulo: Ed. UNESP, 2010; DIAS, Maria Odila Leite da Silva. A interiorização da metrópole. In: $A$ interiorização da metrópole e outros estudos. São Paulo: Alameda, 2005.
}

${ }^{6}$ HORNAERT, Eduardo; et al. História da Igreja... Op. cit., p. 34-40.

${ }^{7}$ Idem. 
confundia-se com a elite intelectual, econômica e religiosa, tinha grande interesse em exercer controle local sobre o aparelho burocrático religioso, no intuito de instrumentalizá-lo às suas demandas, particularmente, os processos de dispensas matrimoniais, frutos das uniões endogâmicas, que exigiam dos seus requerentes desgaste político, econômico e social, pela necessidade de autorização da jurisdição maranhense.

As Cortes de Lisboa propiciaram ocasião para a Colônia levar à ordem portuguesa estabelecida as necessidades mais urgentes dos potentados locais. ${ }^{8}$ Deste modo, em sessão de 14 de setembro de 1822, o representante piauiense, Miguel Sousa Borges Leal, ${ }^{9}$ levou ao conhecimento formal a necessidade de criação de uma diocese no Piauí, o que implicaria no desmembramento do bispado do Maranhão, que exercia jurisdição sobre a maior parte do território do Piauí e sua capital, Oeiras, desde $1724,{ }^{10}$ e sobre todo o território "por desistência que dela fez o Exmo. Bispo D. Frei José Fialho", da diocese de Pernambuco. ${ }^{11}$

É de se considerar a relevância do tema para o Piauí, posto em pauta a frente de tantas outras demandas da época. Se a temática da criação de uma diocese independente ao Maranhão foi levada à discussão por sujeito legitimado, investido de capacidade de catalisar as principais queixas locais, sobretudo, da elite política, como o era o ilustre deputado das Cortes, é razoável afirmar que o tema era relevante e que a autonomia espiritual preocupava o meio social oitocentista, embrionada mesmo antes daquela oportunidade, ${ }^{12}$ aproveitando as Cortes Constitucionais como tribuna privilegiada para o atendimento das solicitações de maior importância para o Piauí.

\footnotetext{
${ }^{8}$ Cf.: CARVALHO, Manuel Emílio Gomes de. Os deputados brasileiros nas... Op. cit.

${ }^{9}$ Apesar do homônimo, este Miguel Leal (1778-1844) não é o mesmo Miguel de Sousa Borges Leal Castelo Branco (1836-1887) que escreveu Apontamentos biográficos de alguns piauienses ilustres e de outras pessoas notáveis que ocuparam cargos importantes na província do Piauí. (Brasília; Teresina: Senado Federal; APL, 2012). O primeiro foi biografado na obra do segundo. Para além das virtudes exaltadas naquele tipo de literatura, sabe- se que compôs a lista tríplice como candidato ao Senado do Império, juntamente com João Severino Maciel da Costa e o escolhido, Luís José de Oliveira Mendes. Além de ter sido deputado pelo Piauí nas Cortes de Lisboa, foi magistrado, era piauiense, e teve sua formação em Coimbra. Cf.: BRANDÃO, Wilson de Andrade. História do Poder Legislativo na Província do Piauí. $2^{\mathrm{a}}$ ed. Teresina: APL, 2015, p. 94.

10 MEIRELES, Mário Martins. História da Arquidiocese de São Luís do Maranhão (no tricentenário de criação da diocese). São Luís: Universidade do Maranhão; SIOGE, 1977, p. 116.

11 Pereira da Costa lembra que a antiga jurisdição eclesiástica de Pernambuco sobre o Piauí permaneceu em parte do território, na região de Parnaguá, extremo sul da Capitania, até data desconhecida, quando foi constituída freguesia e desmembrada da freguesia pernambucana de São Francisco da Barra do Rio Grande do Sul, ainda que, antes, por desistência do bispo de Pernambuco, Dom frei José Fialho (1725-1738), estivesse desassistida daquele bispado, que declinou em razão da distância da sede do bispado em relação àquela localidade, o que dificultava a ação pastoral. IBGE. Município de Paranaguá. Disponível em: https://biblioteca.ibge.gov.br/visualizacao/dtbs/piaui/parnagua.pdf. Acesso em: 20 out. 2018; COSTA, Francisco Augusto Pereira da. Cronologia histórica do estado do Piauí. Vol. 1. 3a ed. Teresina: APL, 2015, p. 54; COUTO, D. Domingos do Loreto. Desaggravos do Brasil e Glorias de Pernambuco. Rio de Janeiro: Offina Typographica da Bibliotheca Nacional, 1904, p. 168.

12 Leoni remete ao ano de 1744 como início da ideia de um bispado independente no Piauí, ainda que muito vagamente, pois: "a grandeza deste novo mundo, a bondade do seu clima e a fertilidade das suas terras em que pelo tempo adiante será preciso fundar outro bispado [separado do Maranhão]". LEONI Apud SANTOS NETO, Antonio Fonseca dos; LIBÓRIO, Paulo de Tarso Batista. Dom Joaquim. Teresina: Nova Aliança, 2016, p. 43.
} 
$\mathrm{Na}$ maior parte do século XIX, as conveniências políticas direcionaram as questões pastorais. Em verdade, apesar de não se poder desconsiderar os sentimentos religiosos daqueles homens estavam embebidos da mentalidade regalista, onde a instrumentalização da Igreja pelo Estado era tida como necessária, legal e desejada. Desta forma, para além da frágil assistência espiritual, um chauvinismo entre a província do Piauí e a província do Maranhão era perceptível, onde o véu religioso apenas escondia a necessidade de uma maior autonomia da elite política piauiense em face da elite eclesiástica do Maranhão, e assim gozar de todos os benefícios dos usos e abusos da Igreja pelo Governo local, num claro interesse jurisdicional.

As questões levadas às Cortes buscavam, dentre outras, dirimir as divergências de governança entre o Piauí e o Maranhão, o que evidencia que a paulatina autonomia experimentada pelo Piauí afetava tanto a elite piauiense, quanto a maranhense, de modo a motivar a primeira, por meio de seu representante nas Cortes de Lisboa, a denunciar os limites de sua autonomia e reivindicar melhorias:

Há sessenta anos que os portugueses do Piauí começaram a melhorar de fortuna com a providência aplicada a alguns de seus males e precisões; até esse tempo eles viveram inteiramente privados da fruição das vantagens, e do bem-estar, de que gozam os indivíduos de uma sociedade bem estabelecida. João Pereira Caldas foi o primeiro mandado para governar estes povos em 1753, e pouco depois Ihe foi dirigida a carta de lei de 19 de junho de 1761, pela qual o sr. Rei D. José mandou fundar as vilas do Piauí nas mesmas freguesias existentes, e houve por bem, depois de fundadas, e estabelecidas as ditas vilas, de criar a da Mocha, que já tinha sido ereta no reinado do sr. D. João $\mathrm{V}$, em 1718 , em cidade capital para nela residir o governo de toda a província, e de conceder assim aos oficiais da Câmara desta cidade, como aos das Câmaras das vilas certas isenções, liberdades, e prerrogativas. Teve esta lei sua execução em 1762, sendo Governador o mencionado João Pereira Caldas, e ouvidor geral Luiz Duarte Freire. A província do Piauí, que foi comarca do Maranhão até 1718 , recebeu aquele seu primeiro governador 40 anos depois da época da sua criação, que foi no mesmo ano de $1718 .^{13}$

A fala de Borges Leal rememora a trajetória político-administrativa do Piauí, ressaltando os feitos da administração lusitana sobre aquele território, de tal modo que, essas mudanças foram sensíveis aos moradores, especialmente aos reinóis que eram afetados pela administração transatlântica.

Após descrição elogiosa e associada à jurisdição do Maranhão, Borges Leal, deputado piauiense junto as Cortes, redireciona seu discurso na intenção de contestar a eficácia da sujeição vivida do Piauí ao Maranhão. Frente a uma nova realidade narrada por ele mesmo, denuncia a própria indiferença do Governo português à situação do Piauí, desta vez, a despeito da subordinação política em relação ao Maranhão:

Não cansarei de certo os doutos Membros deste soberano Congresso com narrações tristes, desagradáveis, e impróprias do fim que levo em vista nesta

\footnotetext{
${ }^{13}$ Indicação do deputado do Piauí Miguel Sousa Borges Leal. Sessão de 14 de setembro de 1822. In: Cortes Gerais e Extraordinárias da Nação Portuguesa, Lisboa, n. 37, 14 set. 1822, p. 435-436. Disponível em: http://debates.parlamento.pt/catalogo/mc/c1821/01/01/01/037/1822-09-14. Acesso em: 5 maio 2018.
} 
minha indicação, reconhecendo não ser este o lugar oportuno para elas. Criada, pois a capital do Piauí, e as vilas Paranaguá, Valença, Jerumenha, Marvão, Campo Maior, e Parnaíba. Que bens! Que aumento teve depois dessa criação? Costumando a ser a mesma província, e uma só comarca obteve ser desmembrada, e instalada em província independente do Maranhão, no que foi sujeita até 1811. Obteve um só juiz de fora das duas vilas Parnaíba e Campo Maior, distantes uma da outra 60 léguas, ou pouco menos, e alfandega na Parnaíba: outro juiz de fora na cidade de Oeiras, e uma cadeira de latim, a qual me consta estar dignamente ocupada; algumas escolas públicas de primeiras letras, mas com o ordenado de $50 \$$ reis ou $60 \$$ reis anualmente, que convidou para professores delas unicamente a indivíduos, que nem são capazes de ser decuriões em escolas presididas por homens doutos, e versados no conhecimento das primeiras letras, da moral e da política, únicos habilitados para a educação da mocidade, uma junta da fazenda nacional na mesma cidade, algumas companhias de tropas de linha: um regimento de cavalaria miliciana na Parnaíba composto de doze companhias (segundo sou informado), o qual somente tem servido de oprimir e empobrecer os indivíduos de que se compõe, além de outros muitos milicianos espalhados, e situados em diferentes distritos da província, e conseguintemente comandantes, e inspetores. Eis os bens, e aumento que obteve a província do Piauí, depois da época da fundação e criação da sua capital e vilas. E por ventura os portugueses do Piauí estarão contentes e satisfeitos com a aquisição desses bens, e com esse aumento? Nada mais terão a desejar? Certamente, que a felicidade deles muito pouco se tem promovido, e adiantado. Muitos objetos, e mesmo parte dos indicados bens, precisam de muito exata e rigorosa reforma, e melhoramento; irei tratando deles em tempo oportuno. ${ }^{14}$

Os questionamentos do representante piauiense evidenciam a indolência, sentida pela elite local, dos seus governantes. Entretanto, não se refere unicamente ao passado elogioso de implantação do aparelho estatal naquela região, isto é, dos primeiros avanços locais. Remetendo ao contexto político-administrativo que Ihe sucedeu, marcado pelo atrito com as lideranças do Maranhão, sugere que não houve mudança no cenário piauiense a partir daquela jurisdição, tanto por passividade da Corte, que desde 1808 residia no sul do Brasil (Rio de Janeiro), como por herança malograda da dependência do Maranhão.

Aponta, pois, Borges Leal, após longa preparação dos seus ouvintes, o cerne de sua argumentação, ao discutir aspectos diversos de governança e sujeição, que remete ao elemento de dependência que mais incomodava a elite local, por seus efeitos sobre a organização sócio familiar da Província, a subordinação espiritual à Diocese do Maranhão:

\section{O Sr. Borges Leal leu o seguinte INDICAÇÃOO}

[...] Agora somente tenho em vista as mesmas justíssimas razões da lei de 19 de junho de 1761 tendentes a promover, e facilitar a administração dos sacramentos, e observância das leis na província do Piauí, de cuja vastidão resultam imediatamente muitos e grandes incômodos, e despesas aos seus habitantes, que por isso mesmo ardentemente desejam conseguir certas desmembrações, e divisões do vasto território que habitam. Por tanto, em benefício dos mesmos, proponho:

rio que habitam. Por tanto, em benefício dos mesmos, proponho:

\footnotetext{
${ }^{14}$ Indicação do deputado do Piauí Miguel Sousa Borges Leal. Sessão de 14 de setembro de 1822. In: Cortes Gerais e Extraordinárias da Nação Portuguesa, Lisboa, n. 37, 14 set. 1822, p. 435- 436. Disponível em: http://debates.parlamento.pt/catalogo/mc/c1821/01/01/01/037/1822-09-14. Acesso em: 5 maio 2018.
} 
10 A desanexação do Piauí do bispado do Maranhão, criando-se uma nova diocese na cidade de Oeiras do mesmo Piauí. ${ }^{15}$

A solicitação do representante piauiense se respalda na lei, que segundo o mesmo, coincide com a vontade dos habitantes do Piauí, pelos sofríveis "grandes incômodos" oriundos da obrigação leiga de gozar dos sacramentos, e da Igreja de Ihes fornecer. Todavia, segundo observava o representante piauiense, não eram atendidas em função de uma suposta deficiente estrutura eclesial naquela província.

\section{Governança Plena: Sacro-Cartorialidade Social}

Em reforço ao seu argumento para criação no Piauí de uma nova diocese, Borges Leal invoca a amplitude espacial, marcada pela "vastidão" do território e a inadequada distribuição destas unidades eclesiais. ${ }^{16}$ Assim, exigia "desmembrações, e divisões" de modo a prover os piauienses do serviço litúrgico, despendido pela Igreja Católica, gerenciada por seus bispos, e, ordinariamente, operadas nas paróquias pelos padres.

Os sacerdotes desempenhavam o múnus pastoral nos ambientes sacros, todavia, não se limitavam a esses lugares. Uma vez inseridos na sociedade, atuavam muito além do exercício público do culto, praticando atividades diversas, ${ }^{17}$ com destaque para a vida política, transitando entre o púlpito e o palanque e entre o átrio e as assembleias políticas, muitas vezes, confundindo-os. Neste quesito, a indicação nas Cortes de criação de um bispado também pode ser vista pela presença destes sujeitos nas esferas de poder político, direta ou indiretamente.

É o que se pode perceber quando um dos deputados piauienses na ocasião das Cortes seria o Padre Marcos de Araújo Costa, clérigo pertencente a um importante entroncamento familiar do período, que, enquanto padre-político, não participou diretamente das Cortes, mas, provavelmente, manteve contato com Borges Leal no intuito de levantar a questão de um bispado independente do Maranhão. ${ }^{18}$

De fato, aquelas elites prescindiam de um padre para orientar suas demandas religiosas. Todavia, quando esta se relacionava à conjuntura social, o que comumente

\footnotetext{
${ }^{15}$ Indicação do deputado do Piauí Miguel Sousa Borges Leal. Sessão de 14 de setembro de 1822. In: Cortes Gerais e Extraordinárias da Nação Portuguesa, Lisboa, n. 37, 14 set. 1822, p. $435-436$. Disponível em: http://debates.parlamento.pt/catalogo/mc/c1821/01/01/01/037/1822-09-14. Acesso em: 5 maio 2018.

${ }^{16}$ A criação de paróquias, até 1834, constituía-se em ato episcopal. A partir do Ato Adicional de 1834 , que também criou as Assembleias Provinciais Legislativas, deixou sob encargo do legislativo provincial tal prerrogativa. BRASIL. Lei 40, de 3 de outubro de 1834. Dá regimento aos Presidentes de Província, e extingue os Conselhos de Presidência. Disponível em: http://legis.senado.leg.br/legislacao/PublicacaoSigen.action?id=540900\&tipoDocumento=LEIn\&tipoTexto=PUB. Acesso em: 21 jul. 2017.

17 SANTIROCCHI, Ítalo Domingos. Questão de Consciência... Op. cit., p. 159-160.

18 BRANDÃO, Wilson de Andrade. História do Poder... Op. cit., p. 46; SOUSA NETO, Marcelo de. Entre vaqueiros e fidalgos: sociedade, política e educação no Piauí (1820-1850). Teresina: FCMC, 2013.
} 
acontecia pelo imbricamento do Estado e Igreja, a presença de um clérigo no meio exige considerar o reforço destas demandas, e que as questões levadas às Cortes passaram por uma discussão e seleção dentre aqueles atores sociais, definindo-as prioridades da província, com ativa participação de uma elite que se conhecia muito bem, que tinha anseios semelhantes e que, eventualmente, interagiam entre si na velha capital, Oeiras. ${ }^{19}$

Do exposto, como observa Sousa Neto, é consoante que a luta pela criação do bispado tenha sido um dos projetos mais assasses de Pe. Marcos, sacerdote-político, conhecedor das estratégias de domínio e exercício do poder local e no interior da Igreja. ${ }^{20}$ Todavia, apesar de toda mobilização política, e das discussões futuras nos três órgãos de maior poder da província, o Conselho de Presidência, o Conselho Geral de Província, e, na sucessão deste, a Assembleia Provincial, onde o reverendo ocupou cadeira em cada um deles, em parceria com diversos outras lideranças locais, não obteve êxito na criação do bispado prenunciada nas Cortes. ${ }^{21}$

As linhas gerais de reclames de uma diocese do Piauí, neste recorte, permaneceram as mesmas. Explicitamente, era notório que o território do Piauí era muito extenso para a distribuição eclesiástica em voga. Neste quesito, a assistência religiosa provida pela diocese do Maranhão era considerada, pelos anseios piauienses, insuficiente, agravada pelas distâncias geográficas entre a sede do bispado, São Luís, e a capital da Província, até então,

\footnotetext{
${ }_{19}$ Para tal constatação, basta lembrar, dentre outros assuntos abordados nas Cortes, desta vez pelo deputado Domingos da Conceição, vislumbrava medidas para aumento da população e da agricultura, através da utilização de sesmarias incultas. Cf.: Indicação do deputado Domingos da Conceição. In: Cortes Gerais e Extraordinárias da Nação Portuguesa, n. 37, 14 set. 1822, p. 435- 436. Disponível em: http://debates.parlamento.pt/catalogo/mc/c1821/01/01/01/037/1822-09-14. Acesso em: 5 maio 2018.

${ }^{20}$ SOUSA NETO, Marcelo de. Entre vaqueiros e... Op. cit.

${ }^{21}$ Cada um destes órgãos tinha suas atribuições. O Conselho de Governo, de Presidência, ou de Província, foi criado por lei de 20 de outubro de 1823, em substituição às Juntas Provisórias de Governo, instituídas pelo decreto de 29 de setembro de 1821. Decide o Presidente sozinho para assuntos da administração e militares não previstos na lei para apreciação colegial; e em Conselho sobre matérias administrativas, dispostas na sua lei originária, embora, na prática, o Conselho fosse além de suas prerrogativas. Foi extinto em 1834, recaindo suas competências sobre o Presidente da Província. BRASIL. Lei de 20 de outubro de 1823. Dá nova forma aos Governos das províncias, criando para cada uma delas um Presidente e Conselho. In: Coleção das leis da Assembleia Geral Constituinte e Legislativa do Brasil de 1823. Parte I. Rio de Janeiro: Imprensa Nacional, 1887. Disponível em: http://www2.camara.leg.br/atividadelegislativa/legislacao/publicacoes/doimperio/colecao2.html.

Acesso em: 19 maio 2018; BRANDÃO, Wilson de Andrade. História do Poder... Op. cit.; BRASIL. Lei 40, de 3 de outubro de 1834. Dá regimento aos Presidentes de Província, e extingue os Conselhos de Presidência. Disponível

http://legis.senado.leg.br/legislacao/PublicacaoSigen. action?id=540900\&tipoDocumento=LEI-

n\&tipoTexto=PUB. Acesso em: 21 jul. 2017. O Conselho Geral de Província foi criado pela Constituição Imperial de 1824, a partir da garantia de intervenção "de todo cidadão nos negócios da sua província". BRASIL. Constituição Política do Império do Brasil, de 25 de março de 1824. Artigo 74. Disponível em: http://www.planalto.gov.br/ccivil_03/constituicao/constituicao24.htm. Acesso em: 18 jul. 2017. As demandas deste Conselho deveriam ser remetidas ao Executivo Imperial, que as encaminharia à Assembleia Geral, a título de projeto de Lei, restringindo-se, porém, ao âmbito provincial, nos termos do artigo 83 da Constituição, o que também era extrapolado por este Conselho, como exemplificam as tentativas de criação de um bispado no Piauí. Finalmente, a Assembleia Legislativa Provincial substituiu os Conselhos Gerais, todavia, com maior autonomia que o seu predecessor. A partir de 1834, pela emenda à Constituição feita pela Lei no 16 , as províncias tiveram maior autonomia nos negócios locais. Também exacerbaram, por vezes, suas atribuições, como, novamente, exemplifica as leis de criação de um bispado no Piauí. BRANDÃO, Wilson de Andrade. História do Poder... Op. cit., p. 72.
} 
Oeiras; e a maior das distâncias, a distância de interesses, o que colidia frontalmente com a governança.

Ressalte-se que, o domínio político-administrativo não se restringia ao Governo civil. O governo espiritual, exercido pela Igreja Católica compunha parte da burocracia. Neste aspecto, não se governava apenas com atos seculares, requeria-se uma sacro-cartoriedade para dar coesão à sociedade, especialmente pelo governo das consciências, e mesmo para dar validade a diversos atos da vida civil, de prerrogativa da Igreja. ${ }^{22}$ Neste sentido, o governo espiritual foi espaço importante de poder, no qual a elite local não deliberava, devido a Igreja piauiense ser subordinada ao bispado do Maranhão, controle definido pela Coroa, "como que para compensar o Maranhão da perda do Grão-Pará que se emancipara eclesiasticamente em 1719, o Piauí, até então subordinado ao Bispado de Pernambuco, foi transferido para a jurisdição de sua diocese, ao que nos parece, em data de 13/02/1724."23

Nesse mesmo sentido, como observado por Mário Meirelles, as áreas pastorais da Igreja configuraram-se também como objeto de poder e barganha da Coroa, o que resultou em atritos entre aquele que exercia a jurisdição eclesiástica e o que era subordinado, a exemplo dos atritos que resultaram, em 1811, na separação "temporal" entre Piauí e Maranhão.

Contrariamente à independência política-administrativa, a autonomia do governo espiritual do Piauí não foi atendida pelo Governo Colonial, nem Imperial. Apenas após a separação entre Igreja e Estado ocorrerá tal feito, em 1901, apesar de todas as tentativas ao longo do século XIX. ${ }^{24}$

No caso do Piauí, a autonomia política "conquistada" com a separação do Maranhão dava mostras de seus limites, dada a sujeição religiosa, sobretudo ao ser lembrado que, nestes confins do Império, a política não se operava sem a religião, pois, dos laços de compadrio, apadrinhamento e especialmente da união indissolúvel do matrimônio estabeleciam-se os principais aliados políticos, a família e a parentela. ${ }^{25}$

A própria percepção da Igreja como célula nuclear da vida social, elo de contato e trocas que intermediava as diversas peças daquela sociedade, pode ser verificada na relação que era feita a partir da reestruturação proposta nas relações entre freguesias e paróquias, vilas e capelas, e mesmo da administração da justiça através das comarcas, como se percebe pelo discurso de Miguel Borges Leal nas Cortes:

20 A divisão regular das freguesias, erigindo-se novas paróquias nas capelas existentes, e nas freguesias aonde não houver capelas; enquanto elas se não dividirem, e se não fundarem novas igrejas, os párocos deverão ter dois

\footnotetext{
22 SANTIROCCHI, Ítalo Domingos. Questão de Consciência... Op. cit., p. 159-160.

23 MEIRELES, Mário Martins. História da Arquidiocese... Op. cit., p. 116.

24 MELO, Pe. Cláudio de. Piauí, diocese e província eclesiástica. Teresina: Arquidiocese de Teresina, 1993.

25 Sobre este tema, ver: BRANDÃO, Tanya Maria Pires. A Elite colonial piauiense: família e poder. $2^{\mathrm{a}}$ ed. Recife: Ed. UFPE, 2012; LEWIN, Linda. Política e parentela na Paraíba: um estudo de caso da oligarquia de base familiar. Rio de Janeiro: Record, 1993.
} 
coadjutores pelo menos; e tanto a estes, como àqueles se assinará uma côngrua para sua sustentação, e será proporcionada à dignidade do seu ministério, e ao trabalho, e encomendo que tiverem no exercício dele, e paga pelas rendas públicas da província para esse fim destinadas.

30 A desanexação da vila de Santo Antonio de Campo Maior, da de S. João da Parnaíba, criando-se naquela um lugar de juiz de fora, que exercerá sua jurisdição em todo o território da freguesia, em que está situada a mesma vila de Campo Maior.

40 A divisão da comarca, criando-se a segunda que compreenderá os distritos, das três vilas, Parnaíba, Campo Maior, e Marvão, servindo-Ihe de cabeça da comarca a mesma vila de Parnaíba.

- Miguel Sousa Borges Leal. ${ }^{26}$

Muitas mudanças eram requeridas, mas nenhuma delas seria atendida naquele contexto. Na verdade, na sessão em que foram discutidas estas questões levadas pelos deputados piauienses, há exatos 7 dias já haviam sido proclamados a emancipação política do Brasil, reconfigurando-se "sem muitos abalos" a dinâmica política no, agora, Império do Brasil. 27

Deve ainda ser lembrado que os esforços de Borges Leal nas Cortes figuram como um gesto de coerência com princípios defendidos em diversas partes da ainda Colônia, de defesa da unidade entre Brasil e Portugal sob uma única Constituição. Até pouco tempo antes da declaração de Independência, "todos ou quase todos deste lado do Atlântico, inclusive o príncipe e seus ministros, ainda acreditavam garantir os interesses do Reino do Brasil, no interior da união com Portugal". ${ }^{28}$ No Piauí, por exemplo, o movimento de 19 de outubro em Parnaíba, que ainda não havia recebido a notícia da Proclamação de Independência por D. Pedro, proclamou a independência do Reino do Brasil e sua união com Portugal. ${ }^{29}$

Transcorrido aquela tentativa inicial frustrada, resultado das mudanças políticas sofridas, sucedeu-se na vanguarda de requerimentos de brado emancipacionista eclesiástico, as Câmaras Municipais Primeiramente, a Câmara de Jerumenha, seguida, não necessariamente nesta ordem, pelas de: Oeiras, Campo Maior e Marvão (Castelo do Piauí). ${ }^{30}$

Nesta recentíssima realidade do Império, temos o indicativo de que a insatisfação religiosa no Piauí, sobretudo, pela dimensão social na qual a Igreja exercia controle, era sentida nos diversos níveis administrativos. Especialmente nos núcleos populacionais organizados em vilas, onde a dinâmica social é a mais próxima possível entre política e sociedade, podemos dizer que o problema foi diagnosticável com mais clareza:

A Câmara de Jerumenha, nas instruções que deu aos Deputados à Assembleia Geral Legislativa, sobre os objetivos concernentes aos melhoramentos do seu

\footnotetext{
${ }^{26}$ Indicação do deputado do Piauí Miguel Sousa Borges Leal. Sessão de 14 de setembro de 1822. In: Cortes Gerais e Extraordinárias da Nação Portuguesa, n. 37, 14 set. 1822, p. 435-436. Disponível em: http://debates.parlamento.pt/catalogo/mc/c1821/01/01/01/037/1822-09-14. Acesso em: 5 maio 2018.

${ }^{27}$ FAUSTO, Boris. História do Brasil. 12a ed. São Paulo: EdUSP, 2006, p. 146.

28 BERNARDES, Denis Antônio de Mendonça. O patriotismo constitucional: Pernambuco, 1820-1822. São Paulo; Recife: Hucitec; Fapesp; Ed. UFPE, 2006, p. 498.

${ }^{29}$ BRANDÃO, Wilson de Andrade. História da independência no Piauí. Teresina: COMEPI, 1972, p. 114.

30 MELO, Pe. Cláudio de. Piauí, diocese e... Op. cit., p. 11.
} 
termo e da Província, lembrou no artigo $4^{\circ}$ a necessidade geral de desanexarse a Província, do Bispado do Maranhão, havendo nela seu competente Prelado isento. ${ }^{31}$

É sintomática ter sido Jerumenha, uma das primeiras vilas, a relatar a necessidade da criação de um bispado no Piauí. Como evidenciou Tânya Brandão havia naquela comunidade um intenso entrelaçamento familiar, isto é, oficializado na Igreja e no Estado pelo sacramento do matrimônio, os membros de uma mesma família, se uniam em casamento, visando à manutenção e ampliação do patrimônio e a formação de uma rede familiar que se projetasse sobre o domínio social, político e econômico. ${ }^{32}$

Desta relação entre Matrimônio e endogamia é que a Igreja emerge como protagonista, pois, uma vez monopolizado o sacramento do matrimônio pela mesma, único reconhecido pelo Estado na ausência de um registro civil, cabia à mesma analisar e validar.

Nos casos especiais, de parentesco ou afinidade entre os nubentes, cabia aos bispos, ter um cuidado maior, exigindo para estes casos, uma dispensa especial, dada diretamente pelo Papa, ou ainda, por intermédio de seu delegado, isto é, pelo Núncio Apostólico, e, teoricamente, extraordinariamente, por um bispo, desde que autorizado para tal fim. Procedia, assim, seguindo critérios e limitações da Santa Sé, que normalmente concedia por negociações diplomáticas, todavia, limitando-as em número, período, dispêndio e especificidade da união. ${ }^{33}$

A Igreja era bastante criteriosa neste quesito, de modo que, a amplitude dos casos em que era necessário o pedido de dispensa, figurava-se como uma barreira quase intransponível no contexto do Piauí oitocentista, uma vez que, muitas uniões, construídas suas linhagens nos séculos anteriores em igual prática, eram parentais. ${ }^{34}$ As Constituições do Arcebispado do Bahia são taxativas, neste quesito:

É esta de três de matérias, natural, espiritual, e legal. Natural, se os contraentes são parentes por consanguinidade dentro do quarto grau Espiritual, que se contrai nos Sacramentos do Batismo, e da Confirmação, entre o que batiza, e o batizado, e seu pai e mãe; e entre os padrinhos, e o batizado, e seu pai e mãe; e na mesma maneira no Sacramento da Confirmação. Legal, que provem da perfeita adoção, e se contrai este parentesco entre o perfilhante, e o perfilhado, e os filhos do mesmo, que perfilha, enquanto estão debaixo do mesmo poder, ou dura a perfilhação. É

\footnotetext{
31 MELO, Pe. Cláudio de. Piauí, diocese e... Op. cit., p. 11-12.

32 BRANDÃO, Tanya Maria Pires. A Elite colonial piauiense... Op. cit., p. 148-149. Wilson Brandão lembra que oito famílias entrelaçadas dominaram o Piauí: os Souza Martins, os Pereira da Silva, os Coelho Rodrigues, os Vieira de Carvalho, os Sousa Mendes, os Sousa Rabelo, os Costa Araújo e os Araújo Costa. BRANDÃO, Wilson de Andrade. História do Poder... Op. cit., p. 61.

33 Sobre a legislação acerca do casamento no Brasil, antes e depois da independência, ver: SANTIROCCHI. Ítalo Domingos. O Matrimônio no Império... Op. cit., p. 82-83. Cf., também, o "Breve dos 25 anos", de 1796, e suas renovações, de 1822 e 1846. SANTIROCCHI. Ítalo Domingos. O Matrimônio no Império... Op. cit., p. 85-87. Além do breve Facultates quas gravissimis causis ad ducti, de 1873; GÉRSON, Brasil. O Regalismo brasileiro. Rio de Janeiro; Brasília: Cátedra; INL, 1978, p. 133135.

${ }^{34}$ BRANDÃO, Tanya Maria Pires. A Elite colonial piauiense... Op. cit. p. 150-151.
} 
bem assim entre a mulher do adotado, e adotante, e entre a mulher do adotante, e adotado. ${ }^{35}$

Não menos ampla era aquela relativa à afinidade, estendendo ainda mais a rede de proteção criada pela Igreja:

Convém saber, que marido pelo Matrimônio consumado contra afinidade com todos os consanguíneos de sua mulher até o quarto grau, e assim, morta ela, não pode contrair Matrimônio com alguma sua consanguínea dentro dos ditos graus. E da mesma maneira a mulher contrai afinidade com todos os consanguíneos de seu marido até o quarto grau. Também a contrai aquele que tiver cópula ilícita perfeita, e natural com alguma mulher, ou mulher com algum varão; e por esta causa não pode contrair Matrimônio com parente do outro por consanguinidade dentro do segundo grau. ${ }^{36}$

Como se percebe, o poder de unir homem e mulher perante Deus no laço indissolúvel sacramental era importantíssimo para aquela sociedade, considerando, dentre outros aspectos, suas implicações civis, de modo a ecoar em toda a sociedade.

Permitia celebrar alianças, conjugar tratos e destratos, preservar fortunas familiares, e por vezes, amplia-las pelas redes de parentesco que se espraiavam num ímpeto expansionista de elitização e domínio de diversos espaços sociais, onde podemos exemplificar no caso da família Sousa e suas variantes. Sob jugo desta família, havia o Presidente da Província, Manoel de Sousa Martins, que por sua vez, tinha por vice seu primo (por ter sido o mais votado para o Conselho da Presidência de Província), o atuante padre Marcos de Araújo Costa. Seguindo a linha sucessória na Presidência da Província, por $2^{\circ}$ mais votado, o irmão deste último, Inácio Francisco de Araújo Costa, todos membros de mesmo tronco familiar, altamente articulado ao poder público.

O domínio familiar, ela benção da Igreja, estabelecia e expandia as uniões entre famílias e suas ramificações. Assim, é possível compreender a intensidade que a elite política procurou domesticar a Igreja no Piauí, tirando-a da elite eclesiástica maranhense. Neste sentido, atuou o Conselho Geral da Província, alegando os constrangimentos provocados pelas dispensas matrimoniais:

Aos 12 dias do mês de junho de 1829 da Independência e do Império nesta cidade de Oeiras, no Palácio do Governo aonde se fazem as Sessões do Excelentíssimo Conselho [...] se levasse ao alto conhecimento de Sua Majestade O Imperador, a necessidade de haver na Capital desta Província, um delegado do dito Excelentíssimo Ordinário Diocesano, com ampla jurisdição em ambos os foros, e subdelegação das faculdades relativas ao Matrimônio, comedidas no Breve Apostólico de 4 de outubro de 1822; e tomando-se em consideração a matéria, tendo se lembrado os senhores conselheiros de alguns casamentos, que se não realizaram por causa da demora da sentença da dispensa, que alcançada a custo de grandes quantias, tem aqui chegado depois da morte dos contraentes, e de outros que não

\footnotetext{
35 VIDE Apud SANTIROCCHI, Ítalo Domingos. O Matrimônio no Império... Op. cit., p. 84. Disponível em: http://dhi.uem.br/gtreligiao/index.html. Acesso em: 12 ago. 2014.

${ }^{36}$ Ibidem, p. 85.
} 
tiveram lugar, por falta de Procuradores que tivessem amizade na Câmara Eclesiástica. ${ }^{37}$

A alegação do Conselho identifica as concessões da Santa Sé em relação ao matrimônio, expressa no Breve Apostólico. Cientes desta abertura, tentaram territorializá-la ano Piauí, de modo que articula a autoridade papal a do Imperador, para obter as prerrogativas típicas de um bispo. Todavia, como políticos maduros que eram, percebendo as dificuldades impostas pelo Governo Imperial, seja na esfera civil, através do Executivo do Império, seja na esfera religiosa personificada no bispado de São Luís do Maranhão, declinam desta condição ideal, isto é, o bispado, enquanto entidade plena, referenciado no primeiro requerimento de 1822 , para algo menor, porém, mais possível, que chamariam de subdelegação.

Neste caso, permaneceria a subordinação à diocese maranhense, porém, no sentido prático, o bispado Ihes serviria à priori para exercer a capacidade agregadora do matrimônio, de modo a permitir mais facilmente negociar as vantagens inerentes às associações de sobrenome. É neste sentido que o objetivo da solicitação foi esclarecido:

para se concluam aqui mesmo os autos que se processam nos casos de impedimentos para casamentos, que tem sido até agora remetidos, para serem sentenciados na cidade [de São Luís] do Maranhão, devendo- se esperar que mediante a soberana proteção de sua majestade imperial, sendo concedida a dita subdelegação, sessarão os gravíssimos inconvenientes que tanto impedem o bem espiritual dos habitantes na mesma província, e o progressivo aumento de sua população. ${ }^{38}$

O aumento de prerrogativas relativas às dispensas matrimoniais a um padre no Piauí era requerido. No caso, o escolhido deveria ser o vigário da capital, Oeiras, para tratar, especialmente, no que se refere às questões matrimonias, "gravíssimo inconveniente", ao tempo que garantiria autonomia local sobre questões sensíveis aquela sociedade.

Deve-se considerar que solicitações de dispensa matrimonial incorriam em inescapáveis custos processuais, majorados pela distância entre residentes no Piauí e a sede do bispado, taxas e intermediários. A burocracia processual letárgica, a distância e os difíceis caminhos entre São Luís, sede da diocese, e Oeiras, ocasionava que, por vezes, a concessão da dispensa matrimonial chegar apenas após a morte dos contraentes. ${ }^{39}$ Neste sentido, toma a palavra o Conselheiro Pe. Marcos Araújo Costa, para justificar, enfim:

sendo esta Província, quanto ao Governo Eclesiástico, sujeita a do Maranhão, e distando uma da outra Capital cento e cinquenta léguas, além da grande extensão do seu território, era incalculável o incômodo, e detrimento, que pudessem os habitantes dela, em consequência das dificuldades do recurso ao

\footnotetext{
37 PIAUÍ. Arquivo Público do Estado do Piauí. Ata da $4^{a}$ Sessão do Conselho Geral (de Presidência) da Província do Piauí, de 12 de junho de 1829. Sala do Poder Executivo. Atas do Conselho Geral da Província do Piauí (1829-1831). Códice no 520.

38 Idem.

39 Segundo Pe. Cláudio de Melo há um exagero dos Conselheiros nesta afirmação. MELO, Pe. Cláudio de. Piauí, diocese e... Op. cit., p. 12.
} 
Excelentíssimo Ordinário Diocesano, tanto por causa das delongas, que muitas vezes malogram as suas pretensões, e as privam de oportuno remédio as suas necessidades espirituais, como pelas excessivas despesas de portadores que nem sempre se acham suficientes, e que queiram ou possam romper um caminho tão extenso, e arriscado, por causa dos invernosos rios, e perigosa passagem do mar que medeia. ${ }^{40}$

Estava, pois, justificada, no seu entender, a demanda piauiense. Além disso, em situações semelhantes, em que mais de uma província estavam sob o mesmo bispado, não seria fato novo conceder a um vigário geral prerrogativas episcopais. Assim, defendeu Pe. Marcos, no sentido que, dar maior autonomia religiosa a uma província politicamente independente, aumentando faculdades que seriam de difícil obtenção na sede episcopal, foi experimentado em Goiás e de Cuiabá, subordinadas ao bispado do Rio de Janeiro, como é lembrado no Conselho Geral da Província, tal precedente: Resolveu- se que se pedisse a Sua Majestade O Imperador pela Secretaria de Estado dos Negócios da Justiça à graça de mandar expedir Sua Imperial determinação, a fim de que o reverendo bispo do Maranhão, subdelegue ao vigário geral desta província do Piauí as mesmas faculdades que beneficie dos povos foram dadas pelo reverendo bispo do Rio de Janeiro ao Vigário Geral que teve em Goiás, e ao Vigário da Vara de Cuiabá, quando estas províncias eram do seu bispado, para se concluam aqui mesmo os autos que se processam nos casos de impedimentos para casamentos, que tem sido até agora remetidos, para serem sentenciados na cidade do Maranhão, devendo- se esperar que mediante a soberana proteção de sua majestade imperial, sendo concedida a dita subdelegação, sessarão os gravíssimos inconvenientes que tanto impedem o bem espiritual dos habitantes na mesma província, e o progressivo aumento de sua população. ${ }^{41}$

Não cedeu o Governo Central às pressões da elite local do Piauí, ao menos nos termos que queriam, naquele embrião de autonomia. A pretensão da elite piauiense era decidir sobre enlaces matrimonias endogâmicos, que em termos legais eram concedidos em caráter extraordinário. A vivência em sociedade nos sertões do Piauí, entretanto, ocasionou o contrário. Isto é, o que era para ser exceção, o casamento por membros de uma mesma família, tornou-se ordinário, compondo os costumes, e fazendo das determinações eclesiais das Constituições Primeiras do Arcebispado da Bahia, de 1707, por meio das dispensas aplicadas pelos bispos, fonte de renda muito útil ao governo episcopal que Ihe administraria, uma vez que, fugia dos restritos orçamentos do Estado regalista.

As lideranças do bispado do Maranhão sofriam as limitações econômicas impostas à Igreja pelo Estado, e ciente do exclusivismo dos seus serviços, não cederiam facilmente às rendas das dispensas matrimoniais, que, certamente, na impossibilidade de recolherem

\footnotetext{
40 PIAUÍ. Arquivo Público do Estado do Piauí. Ata da 4a Sessão do Conselho Geral (de Presidência) da Província do Piauí, de 12 de junho de 1829. Sala do Poder Executivo. Atas do Conselho Geral da Província do Piauí (1829-1831). Códice no 520.

${ }^{41}$ Idem.
} 
diretamente os dízimos, complementavam com doações de fiéis e taxas processuais e celebrativas os parcos recursos que recebiam do Governo. ${ }^{42}$

Observa-se então, em outros termos, que a elite política piauiense, enquanto principal utilizadora do casamento endógeno para manutenção, ampliação e reconhecimento legal do patrimônio oriundo destas uniões, encontrava-se totalmente dependente da diocese sediada e dirigida por outra elite, eclesiástica e maranhense por naturalidade ou filiação, que a utilizaria em benefício de sua sustentação e investimento.

Segundo Pe. Cláudio de Melo, a solicitação do Conselho Geral da Província passou, primeiramente, pelo Ministério da Justiça, que o faria chegar à diocese do Maranhão, à época governada pelo cônego José Constantino Gomes de Castro, o qual, observando a delicadeza do tema, recolheu- se em aguardo do bispo para análise e parecer. ${ }^{43}$

Portanto, por esta lógica, a mitra maranhense teria um grande peso sobre esta decisão, inclusive por ser ela a mais afetada, ainda que não necessariamente determinante. A política de concessões do Governo em relação à Igreja seguia pelo olhar da mais valia, isto é, toda e qualquer nova jurisdição só teria razão de ser quando atendesse aos seus interesses de domínio, herdado em parte da Colônia quando se observa que as vigararias de Cuiabá e Goiás foram destacadas na condição de prelazias devido ao interesse nas fronteiras; ${ }^{44}$ na associação desta característica com o apaziguamento de forças, onde a diocese de São Pedro do Rio Grande do Sul (1848) erige-se após a Farroupilha; e nos locais de intensa dinâmica econômica, caso específico da diocese Diamantina (1854).

Se de um lado havia a perspicácia governativa do Império e o prestígio da mitra maranhense, do outro tínhamos uma elite piauiense aparentemente coesa, onde seus membros transitavam entre os demais órgãos governamentais provinciais, como é sentida com a presença simultânea de membros no Conselho de Governo e, posteriormente, no Conselho Geral da Província, dando reforço às pautas em favor de uma maior autonomia eclesiástica do Piauí, potencializando-as ao fazê-las circular em outras instâncias de poder local. ${ }^{45}$

A partir da discussão, poderia se remeter ao centro de decisões do Império, de verdadeira competência para divisão eclesiástica em nível interprovincial, isto é, a

\footnotetext{
42 OLIVEIRA, D. Oscar de. Os dízimos eclesiásticos do Brasil nos períodos da Colônia e do Império. Belo Horizonte: Universidade de Minas, 1964.

43 MELO, Pe. Cláudio de. Piauí, diocese e... Op. cit., p. 12; PACHECO, D. Filipe Condurú. História Eclesiástica do Maranhão. Maranhão: SENEC; Departamento de Cultura, 1969, p. 139. Dom Marcos tomou posse da diocese do Maranhão a 19 de março de 1828, por procuração ao cônego José Constantino Gomes de Castro e José João Beckman e Caldas, todavia sua chegada a São Luís e entrada solene na Catedral ocorreu apenas em 11 de março de 1830, o que explica a atitude do Cônego.

${ }^{44}$ CORBALAN, Kleber Roberto Lopes. A Igreja Católica na Cuiabá Colonial: da primeira Capela à chegada do primeiro Bispo (1722- 1808). 2006. Dissertação (Mestrado em História) - Instituto de Ciências Humanas e Sociais, Universidade Federal de Mato Grosso, Cuiabá, p. 42-43.

45 Brandão percebe essa dupla filiação nos seguintes nomes: Marcos de Araújo Costa, João Nepomuceno Castelo Branco, Inácio Francisco de Araújo Costa e Arnaldo José de Carvalho, todavia, a partir de lei de 12 de agosto de 1831 tiveram que optar entre um e outro. BRANDÃO, Wilson de Andrade. História do Poder... Op. cit., p. 99.
} 
Assembleia Geral do Império, onde se analisava a conveniência de criação de bispados. Fazia chegar, pois, o Conselho Geral suas demandas à Assembleia Geral, na forma de seu regimento, a exemplo da resolução de criação do bispado independente do Piauí, em 30 de janeiro de $1833 .{ }^{46}$

Prova do trânsito destes políticos nos espaços de governo, em que enfatizam suas demandas, foi a feita pelo duplo conselheiro Arnaldo José de Carvalho, ${ }^{47}$ que em 12 de dezembro de 1829, propôs ao Conselho Geral

a criação de uma dignidade prelatória independente para o Piauí, que 'acudindo com pronto remédio os males que refiro, faça aparecer o nosso catolicismo em todo o seu esplendor, e chame a um só rebanho todas as ovelhas, que dispersas, ou per perdidas do pastor, divagam por esta imensidade de terreno. Tendo-vos exposto o motivo que me determinaram a falar hoje perante vós se não eloquência, porque me falta, ao menos com aquela franqueza que me é própria, e inseparável do honroso cargo que meus concidadãos me confiaram. ${ }^{48}$

De volta ao Conselho, novamente Arnaldo Carvalho insistiu e radicalizou seu requerimento, publicando logo em 30 de janeiro de 1830, a seguinte resolução:

Art. $1^{0}$ - Fica a Província do Piauí separada e desmembrada da jurisdição da Diocese do Maranhão, criando-se e erigindo-se nela um Bispado com a extensão e limites que formam o seu vasto território.

Art. $2^{\circ}$ - O Bispo que se nomear para este Bispado perceberá anualmente a quantia de $2000 \$ 000$ (dois contos de reis) pagos pelo cofre da Fazenda Pública da referida Província, para sua côngrua, sustentação, aposentadoria, esmolas e Vigário Geral. ${ }^{49}$

Este estrato não é bem contextualizado por Pe. Cláudio, todavia, o que há de conclusivo do elencado pelo padre-historiador, é a absoluta falta de competência de um Conselho de Governo criar um bispado em sua província, devido interferir no governo espiritual de outra província, arrogando-se um direito que nem mesmo o titular da jurisdição, a diocese do Maranhão, poderia fazê-lo por si só. ${ }^{50}$

Deste modo, a interpretação que se faz destas discussões do Conselho de Governo em prol da criação de um bispado no Piauí, decorre do que Brandão explica como "sensibilidade política", sobretudo a questões de natureza social, atendendo "a coisa pública, sob os mais diversos aspectos, e o interesse particular, em suas delicadas manifestações, chegam à sua consideração, trazidos pelas partes, ou de ofício, para debate e apreciação". ${ }^{51}$

\footnotetext{
46 BRANDÃO, Wilson de Andrade. História do Poder... Op. cit., p. 141.

47 Padre Cláudio de Melo nos informa que em 30 de janeiro de 1830 o mesmo estava no Conselho de Governo assinando a resolução de criação do bispado no Piauí. MELO, Pe. Cláudio de. Piauí, diocese e... Op. cit., p. 33.

48 BRANDÃO, Wilson de Andrade. História do Poder... Op. cit., p. 138.

${ }^{49}$ MELO, Pe. Cláudio de. Piauí, diocese e... Op. cit., p. 12-13.

50 Embora utilize o termo genérico "Conselho Provincial do Piauí", sabe-se que se trata do Conselho de Governo devido aos membros da reunião elencados por padre Cláudio de Melo. MELO, Pe. Cláudio de. Piauí, diocese e... Op. cit., p. 13.

${ }^{51}$ BRANDÃO, Wilson de Andrade. História do Poder... Op. cit., p. 52-53.
} 


\section{Considerações Finais}

A atitude do Conselho é explicada por Melo por ser uma grande honraria para a província de o Piauí ter um bispado, haja vista o bispo ser autoridade máxima dentro do clero e, figura das mais respeitadas mesmo fora deste meio, destacando-se não apenas dentro da província, como fora dela. ${ }^{52}$

Além do mais, um bispado agrega a complexidade de uma diocese, isto é, juntamente do bispo deveria existir uma estrutura acessória que incorresse em melhoramentos para a província, como a própria igreja catedral, o paço episcopal, algum Seminário para educação e fomento das vocações, e toda a estrutura burocrática de uma diocese, como o Cabido, conhecido por ser o "senado da Igreja", e a Câmara Eclesiástica, que criariam novos postos de exercício de poder e projeção.

Concorrendo neste sentido, Pe. Cláudio lembra que era motivo de perseguição dos piauienses a criação de um bispado local para que, de alguma forma, atendesse às figuras importantes do clero piauiense, como o notório Pe. Marcos Araújo Costa, dando-Ihes os lugares que potencialmente ocupariam, inclusive como epíscopos, elitizando seus escolhidos, exercendo poder não apenas nas instâncias propriamente políticas e administrativas, mas, na burocracia eclesial, fundamental na composição dos projetos de poder, complementandose governo temporal e espiritual.

Em suma, pode-se dizer que a resolução do Conselho de Governo foi um ato de provocação da elite política piauiense, no intuito de pressionar a elite religiosa do Maranhão a ceder a seu intento. No auge de sua mentalidade regalista, tentou forçar uma situação de submissão do poder espiritual maranhense, ignorando-o deliberadamente, num enfrentamento truculento que lhe sobrepunha às próprias forças.

Na verdade, a grande força do Conselho do Piauí estava na vontade, mas que não encontrava respaldo na conjuntura política daquele contexto, em que seu adversário era acalentado pelo poder central, sobrepujando o próprio prestígio do sólio, este elencado por Melo, corroborado por Sales e Sousa Neto, como um dos motivos para o fracasso piauiense. ${ }^{53}$

A disputa entre Piauí e Maranhão se dava no plano da política e se vestia de mitra e báculo. Todavia, para além daquela solene figura, estavam imersos diversos outros interesses, associados ao intento de autonomia político-eclesial. Em suma, as primeiras

\footnotetext{
52 MELO, Pe. Cláudio de. Piauí, diocese e... Op. cit., p. 12.

53 Ibidem, p. 13; SALES, João Vitor Araújo. Ecclesia una: o processo de separação do bispado do Piauí e Maranhão (1822-1903). 2019. Dissertação (Mestrado em História do Brasil) - Programa de Pósgraduação em História do Brasil, Universidade Federal do Piauí, Teresina; SOUSA NETO, Marcelo de. Em nome da fé; em nome dos bens: a criação da diocese do Piauí (1822-1903). Revista Brasileira de História das Religiões, Maringá (SP), Anpuh, v. 4, n. 10, p. 193-200, mai. 2011. Disponível em: http://www.dhi.uem.br/gtreligiao /index.html. Acesso em: 29 jun. 2018.
} 
tentativas que versaram sobre isto, vocalizadas nas Cortes de Lisboa, no Conselho de Governo e no Conselho Geral da Província, eram de uma sintomática questão de jurisdição e de subordinação, construídas ao longo da História do Brasil, especialmente na sua porção setentrional. 


\section{Referências}

\section{Fontes}

BRASIL. Coleção das leis da Assembleia Geral Constituinte e Legislativa do Brasil de 1823. Parte I. Rio de Janeiro: Imprensa Nacional, 1887. Disponível em: http://www2.camara.leg.br/atividadelegislativa/legislacao/publicacoes/doimperio/colecao2.html. Acesso em: 19 maio 2018.

BRASIL. Constituição Política do Império do Brasil, de 25 de março de 1824. Disponível em: http://www.planalto.gov.br/ccivil_03/constituicao/constituicao24.htm. Acesso em: 18 jul. 2017.

BRASIL. Lei n. 16, de 12 de agosto de 1834. Disponível em: http://www.planalto.gov.br/ccivil_03/LEIS/LIM/LIM16.htm\#art1. Acesso em: 18 jul. 2017.

BRASIL. Lei n. 40, de 3 de outubro de 1834. Dá regimento aos Presidentes de Província, e extingue os Conselhos de Presidência. Disponível em: http://legis.senado.leg.br/legislacao/PublicacaoSigen.action?id=540900\&tipoDocumento=LEI -n\&tipoTexto=PUB. Acesso em: 21 jul. 2017.

IBGE. Município de Parnaguá. Disponível em: https://biblioteca.ibge.gov.br/visualizacao/dtbs/piaui/parnagua.pdf . Acesso em: 20 out. 2018.

Indicação do deputado do Piauí Miguel Sousa Borges Leal. Sessão de 14 de setembro de 1822. In: Cortes Gerais e Extraordinárias da Nação Portuguesa, n. 37, 14 set. 1822, p. 435436. Disponível em: http://debates.parlamento.pt/catalogo/mc/c1821/01/01/01/037/182209-14. Acesso em: 5 maio 2018.

Indicação do deputado Domingos da Conceição. In: Cortes Gerais e Extraordinárias da Nação Portuguesa, n. 37, 14 set. 1822, p. 435-436. Disponível em: http://debates.parlamento.pt/catalogo/mc/c1821/01/01/01/037/1822-09-14. Acesso em: 5 maio 2018.

PIAUÍ. Arquivo Público do Estado do Piauí. Ata da $4^{a}$ Sessão do Conselho Geral (de Presidência) da Província do Piauí, de 12 de junho de 1829. Sala do Poder Executivo. Atas do Conselho Geral da Província do Piauí (1829-1831). Códice n. 520.

\section{Bibliografia}

BERNARDES, Denis Antônio de Mendonça. O patriotismo constitucional: Pernambuco, 18201822. São Paulo; Recife: Hucitec; Fapesp; Ed. UFPE, 2006.

BRANDÃO, Tanya Maria Pires. A Elite colonial piauiense: família e poder. $2^{a}$ ed. Recife: Ed. UFPE, 2012.

BRANDÃO, Wilson de Andrade. História da independência no Piauí. Teresina: COMEPI, 1972.

BRANDÃO, Wilson de Andrade. História do Poder Legislativo na Província do Piauí. $2^{a}$ ed. Teresina: APL, 2015.

CARVALHO, José Murilo de. A construção da ordem: a elite política imperial. Teatro de sombras: a política imperial. 4a ed. Rio de Janeiro: Civilização Brasileira, 2008. 
CARVALHO, Manuel Emílio Gomes de. Os deputados brasileiros nas Cortes Gerais de 1821. Brasília: Senado Federal, 2003.

CASTELO BRANCO, Miguel de Sousa Borges Leal. Apontamentos biográficos de alguns piauienses ilustres e de outras pessoas notáveis que ocuparam cargos importantes na província do Piauí. 2a ed. Brasília; Teresina: Senado Federal; APL, 2012.

CORBALAN, Kleber Roberto Lopes. A Igreja Católica na Cuiabá Colonial: da primeira Capela à chegada do primeiro Bispo (1722-1808). 2006. Dissertação (Mestrado em História) Instituto de Ciências Humanas e Sociais, Universidade Federal de Mato Grosso, Cuiabá.

COSTA, Emília Viotti da. Introdução ao estudo da emancipação política do Brasil. In: Da Monarquia à República: momentos decisivos. 9a ed. São Paulo: Ed. UNESP, 2010.

COSTA, Francisco Augusto Pereira da. Cronologia histórica do estado do Piauí. Vol. 1. $3^{\mathrm{a}}$ ed. Teresina: APL, 2015.

COUTO, D. Domingos do Loreto. Desaggravos do Brasil e Glorias de Pernambuco. Rio de Janeiro: Offina Typographica da Bibliotheca Nacional, 1904.

DIAS, Maria Odila Leite da Silva. A interiorização da metrópole. In: A interiorização da metrópole e outros estudos. São Paulo: Alameda, 2005.

FAUSTO, Boris. História do Brasil. 12a ed. São Paulo: EdUSP, 2006.

GÉRSON, Brasil. O Regalismo brasileiro. Rio de Janeiro; Brasília: Cátedra; INL, 1978.

GARCIA, Javier J. Bravo (coord.) História do Brasil Nação: 1808-2010. Vol. 1: Crise colonial e independência, 1808-1830. Madrid; Rio de Janeiro: Fundación Mapfre; Objetiva, 2011.

HORNAERT, Eduardo; et al. História da Igreja no Brasil: ensaio de interpretação a partir do povo: primeira época - período colonial. $5^{\mathrm{a}}$ ed. Petrópolis, RJ: Vozes, 2008.

LEONI, Aldo Luiz. Copiador de algumas cartas particulares do Excelentíssimo e Reverendíssimo Senhor Dom Frei Manuel da Cruz, Bispo do Maranhão e Mariana (17391762). Brasília: Senado Federal, 2008.

LEWIN, Linda. Política e parentela na Paraíba: um estudo de caso da oligarquia de base familiar. Rio de Janeiro: Record, 1993.

MEIRELES, Mário Martins. História da Arquidiocese de São Luís do Maranhão (no tricentenário de criação da diocese). São Luís: Universidade do Maranhão; SIOGE, 1977.

MEIRELES, Mário Martins. História do Maranhão. 2a ed. São Luís: Fundação Cultural do Maranhão, 1980.

MELO, Pe. Cláudio de. Piauí, diocese e província eclesiástica. Teresina: Arquidiocese de Teresina, 1993.

OLIVEIRA, D. Oscar de. Os dízimos eclesiásticos do Brasil nos períodos da Colônia e do Império. Belo Horizonte: Universidade de Minas, 1964.

PACHECO, D. Filipe Condurú. História Eclesiástica do Maranhão. Maranhão: SENEC; Departamento de Cultura, 1969.

SALES, João Vitor Araújo. Ecclesia Una: o processo de separação do bispado do Piauí e Maranhão (1822-1903). 2019. Dissertação (Mestrado em História do Brasil) - Programa de Pós-graduação em História do Brasil, Universidade Federal do Piauí, Teresina.

SANTIROCCHI, Ítalo Domingos. Questão de Consciência: os ultramontanos no Brasil e o regalismo do Segundo Reinado (1840-1889). Belo Horizonte: Fino Traço, 2015. 
SANTIROCCHI. Ítalo Domingos. O Matrimônio no Império do Brasil: Uma questão de Estado. Revista Brasileira de História das Religiões, Maringá (SP), Anpuh, ano IV, n. 12, jan. 2011, p. 82-83. Disponível em: http://dhi.uem.br/gtreligiao/index.html. Acesso em: 12 ago. 2014.

SANTOS NETO, Antonio Fonseca dos; LIBÓRIO, Paulo de Tarso Batista. Dom Joaquim. Teresina: Nova Aliança, 2016.

SOUSA NETO, Marcelo de. Em nome da fé; em nome dos bens: a criação da diocese do Piauí (1822-1903). Revista Brasileira de História das Religiões, Maringá (SP), Anpuh, v. 4, n. 10, p. 193-200, maio 2011. Disponível em: http://www.dhi.uem.br/gtreligiao /index.html. Acesso em: 29 jun. 2018.

SOUSA NETO, Marcelo de. Entre vaqueiros e fidalgos: sociedade, política e educação no Piauí (1820-1850). Teresina: FCMC, 2013.

SOUZA, Laura de Melo e. O diabo e a Terra de Santa Cruz: feitiçaria e religiosidade popular no Brasil colonial. São Paulo: Companhia das Letras, 1986. 